
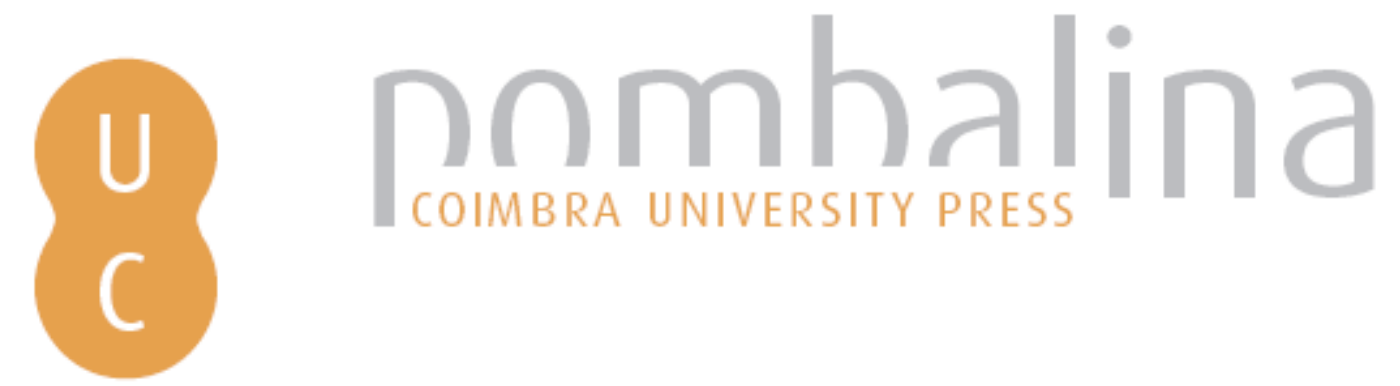

\title{
Results of the R-20F Method for Measuring the Water Equivalence of the Isolation Effect of Foams Used in Fighting Forest Fires
}

\author{
Autor(es): Restas, Agoston \\ Publicado por: Imprensa da Universidade de Coimbra \\ URL \\ persistente: URI:http://hdl.handle.net/10316.2/34221 \\ DOI: $\quad$ DOI:http://dx.doi.org/10.14195/978-989-26-0884-6_163 \\ Accessed : $\quad$ 26-Apr-2023 09:52:15
}

A navegação consulta e descarregamento dos títulos inseridos nas Bibliotecas Digitais UC Digitalis, UC Pombalina e UC Impactum, pressupõem a aceitação plena e sem reservas dos Termos e Condições de Uso destas Bibliotecas Digitais, disponíveis em https://digitalis.uc.pt/pt-pt/termos.

Conforme exposto nos referidos Termos e Condições de Uso, o descarregamento de títulos de acesso restrito requer uma licença válida de autorização devendo o utilizador aceder ao(s) documento(s) a partir de um endereço de IP da instituição detentora da supramencionada licença.

Ao utilizador é apenas permitido o descarregamento para uso pessoal, pelo que o emprego do(s) título(s) descarregado(s) para outro fim, designadamente comercial, carece de autorização do respetivo autor ou editor da obra.

Na medida em que todas as obras da UC Digitalis se encontram protegidas pelo Código do Direito de Autor e Direitos Conexos e demais legislação aplicável, toda a cópia, parcial ou total, deste documento, nos casos em que é legalmente admitida, deverá conter ou fazer-se acompanhar por este aviso.

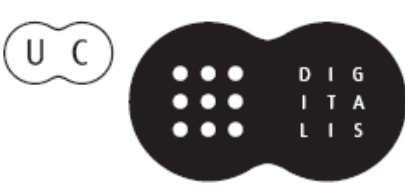




\section{ADVANCES IN}

Forest Fire

\section{RESEARCH}

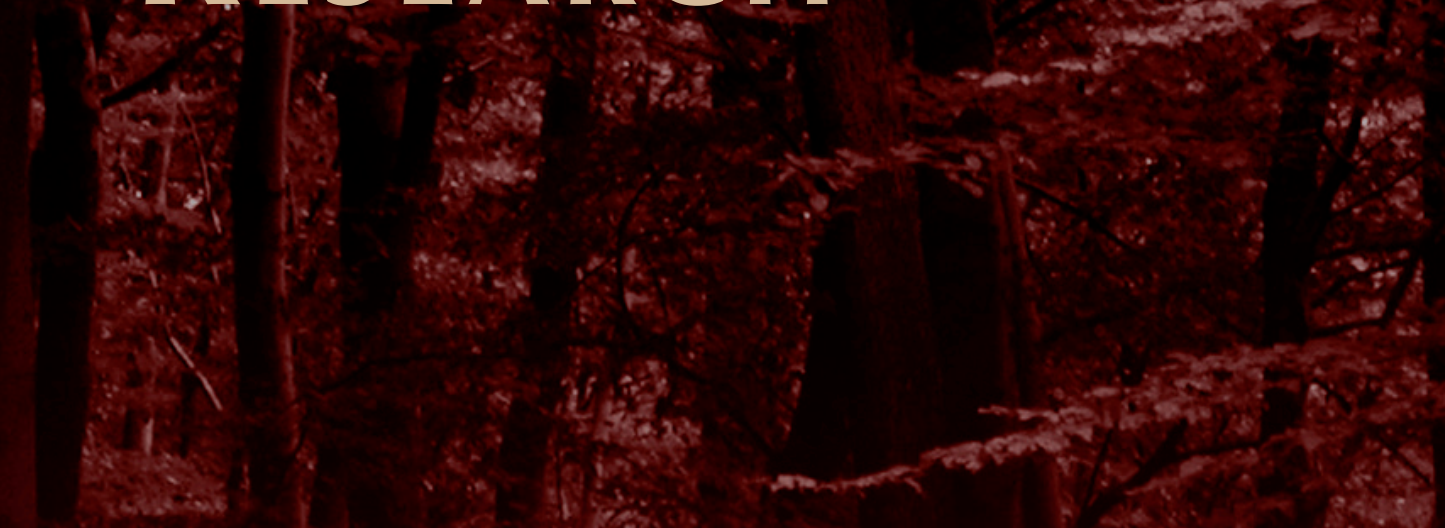

\section{DOMINGOS XAVIER VIEGAS}

\section{EDITOR}




\title{
Results of the R-20F Method for Measuring the Water Equivalence of the Isolation Effect of Foams Used in Fighting Forest Fires
}

\author{
Agoston Restas \\ National University of Public Service, Budapest, Hungary, Restas.Agoston@uni-nke.hu
}

\begin{abstract}
Introduction: Aerial firefighting is a very expensive solution; however bombing just pure water is not always enough to suppress the fires. In many cases retardants or special agents are added to water to increase efficiency, wetting it or creating foam. Methods: This research used dried pine wood pieces as samples. Samples were divided into different groups: not treated samples for giving the reference data or treated samples to ensure data for calculating the isolation effect of foam. During the experiment with a randomly chosen foam agent product a 3\% foam solution was mixed. From this solution 6-9-12 expansion rate foams were generated. Samples were also provided with a metal ring to ensure the exact depth of water or foam blanket. Each sample was put in a special heat oven which ensured the permanent $35 \mathrm{kWm}^{-2}$ heat fluxes and measured the different ignition time. Results and discussion: Experiment demonstrated that the ignition times in case of foams are longer than in case of same equivalent pure water. The longer ignition time of foams can be expressed by the pure water amount. Results say that the maximum rate of isolation effect in value of water equivalent is more than 2.3 but always significantly more than just pure water.
\end{abstract}

Keywords: isolation effect, foam, water equivalence of isolation effect

\section{Introduction}

Based on author's experience there is no objective method known for measuring the complex effect of the efficiency of foams while suppressing fires. The suppression potential of foams such as Class A foams specially used for structure or forest fires is measured by a special way; bonfires classified by international standards are extinguished by the foams and the potential is evaluated by the size of the bonfires. This method, measuring the active impact of foams is appropriate and accepted as international standards for structure fires.

The standard methods are not measuring the isolation effect of foams, however there were more initiatives regarding this topic (Boyd and Merzo, 1996; STP 2007 Standard Test Procedures). But each manufacturer characterizes their agent with the "good" isolation effect. The isolation effect is not an active action against the flame but passive influence of the ignition caused by the blanket covering the surface (Igishev and Portola, 1993; Salgado and Paz-Andrade, 2009).

Since there is no accepted method for measuring the isolation effect of foams, and each producer characterizes its own foam as having " $g o o d$ " isolation effect, it is required to develop a process which is objective, practical and ready to demonstrate the different isolation effects of the different type of foams.

To start with, the reference base to which the effect is evaluated and expressed in equivalent must be declared. Pure water is the most frequently used material for fire suppression that is why it was taken as base and the scale of equivalent.

As usual foam is characterised as having passive isolation effect but not as having the active extinguishing potential; this feature also can be very important during intervention, especially in case of forest fires using aerials. The added value of using foam for the fire suppression is not only isolation of the combustible material against heat radiation but it also plays an active role in suppression. If the quality or quantity of foam blanket is not suited for stopping the spread of fire it means that the consumed resources were ineffective, spending on aerials used was wasteful. 


\section{Methods}

The method was developed in order to measure the extinguishing potential of foam blanket. This procedure following the below assumptions got a fantasy name and was called R-20F method. As usual foam is characterised as having passive isolation effect but not as having the active extinguish potential; however this feature also can be very important during intervention.

\subsection{Prepare the process}

Below is declared the main important things for preparing the test, and some basic process for being ready to measure the ignition time of samples.

Means required for the process:

1. Radiant heater: KAL VK1 $1^{1}$ - with $35 \mathrm{kWm}^{-2}$ heating flux ${ }^{2}$;

2. Samples with metal rings $-0,06 \mathrm{~m} \times 0,06 \mathrm{~m} \times 0,01 \mathrm{~m}$ dried pine wood samples;

3. Pure water, temperature $293 \mathrm{~K}$;

4. Foams, made from type $\mathrm{EVAM}^{3}$ agent, $3 \%$ mixed rate solution, expenditure rate in series $6-9-12$.

Special metal ring stacked to each sample in order to ensure the same thickness of foam blanket covering the samples. Ring is made of steel, with $0.06 \mathrm{~m}$ diameter and $0.008 \mathrm{~m}$ sheet thickness, in series of $2-3-4-5 \mathrm{~mm}$ ring height. Rings are fixed by heat resistant stove glue, purchased from the market.

\subsection{Ignition time}

During the experience three different ignition times were measured: A) It is necessary to measure the natural sample for getting the net ignition time; B) The measurement of the sample treated with water gives the reference base; C) The sample treated with foam is measured for the purposes of the test method.

Ignition time of natural sample: Natural sample with metal ring but without any surface treatment is needed to put in to the radiant heater and measured the ignition time. As usual, the space between the foam blanket and the heater is fix and have to ensure that the radiant heat fluxes is $35 \mathrm{kWm}^{-2}$ continuously. At least 3 or more samples are needed for measuring the ignition times.

Ignition time of water treated sample: The effect of water's ignition delay relates to the ability of heat abstraction; it is used as a base, similar to the effect of foam's ignition delay. Ring on sample is needed to fill with $293 \mathrm{~K}$ temperature pure water by the volume of rings depending on the series. Sample is needed to put in to the radiant heater and measured the ignition time. As usual, the space between the rim of ring and the heater is fix and have to ensure that the radiant heat fluxes is $35 \mathrm{kWm}^{-2}$ continuously. At least 3 or more samples are needed for measuring the ignition times, in series with 2 $-3-4-5 \mathrm{~mm}$ deep water column.

Ignition time offoam covered sample: From pure water and foam agent have to prepare a solution with $3 \%$ mix rate. From the solution different expansion rated foam is prepared in series $6-9-12$. Ring on sample is needed to fill with foam by the volume of rings depending on the series. Sample is needed to put in to the radiant heater and measured the ignition time. The space between the rim of ring and the heater is fix and have to ensure that the radiant heat fluxes is $35 \mathrm{kWm}^{-2}$ continuously. At least 3 or more samples are needed for measuring the ignition times, in series with $2-3-4-5 \mathrm{~mm}$ thick foam blanket.

\footnotetext{
${ }^{1}$ KAL VK1 radiant heater: produced by KALÓRIA Hötechnikai Kft., H-1071 Budapest, Bethlen út 43 Hungary

${ }^{2}$ Certificated by Szent Istvan University, Ybl Miklos Department, Budapest

${ }^{3}$ Foam agent for universal applications in Hungary and neighbor countries, used also for fighting against forest fire; it is made by EVM Rt., H-1172 Budapest, Cinkotai út 26. Hungary.
} 
The effect of foam is obviously influenced both by the structure made by air bulbs and the solution itself the foam contains (water and agent). Since the R-20F method focuses to measuring typically the isolation effect of foam, influence of the solution is needed to exclude. The effect of solution is taken away from the complex effect; it depends on the different quantity in series of the solution the foam contains. Since the extract rate is very low (3\%) the effect of pure water and solution is taken equal. Based on the measured data, it is required to calculate different parameters. For calculations and evaluating the measured value, notations and different mathematical formulas were used. Because of their complexity, formulas (F.x) can be found in the Appendix separated. These formulas marked in brackets signed in many places (text and tables) make the process of following easier.

\section{Study for ignition time}

This study contains only the extracted data meaning usually the average value of measured ignition time but in explanation deviations also mentioned. The whole study located in the author's archive.

\subsection{Measured ignition times of different treated samples}

The first test result used for this study for further calculation. The Table 1 contains the average value of measured ignition time.

Table 1-Measured data of ignition time.

\begin{tabular}{|c|c|c|c|c|c|c|}
\hline & & & & et $\mathrm{s}$ & ered & \\
\hline & $20 \mathrm{~F}$ & treatment & 2 & 3 & 4 & 5 \\
\hline & & & & tir & & \\
\hline & ture & 19 & & & & \\
\hline & ater & & 108 & - & - & - \\
\hline & Rexp6 & & 45 & 51 & 58 & 60 \\
\hline Foam & Rexp9 & & 42 & 47 & 50 & 53 \\
\hline & Rexp12 & & 36 & 44 & 46 & 44 \\
\hline
\end{tabular}

Legend: Nature: samples without treatment $\mathrm{R}_{\mathrm{exp}}$ 6/9/12: Expansion rate of foam used for series

Based on the measured data and mathematical formulas different calculations were made. The series of this calculation can be followed in Table 2, Table 3 and Table 4.

\subsection{Net time of ignition delay}

To evaluate the results different calculations were made. Firstly, the ignition delays of differently treated sample were measured; in case of no treatment (nature) F.13, water F.14 and foam F.16 figures meaning. These results can be evaluated as "net effect" of ignition delay of extinguishing material covering the samples. For the calculations $F .15$ (water) and F.17 (foam) formulas were used (Table 2). 
Table 2-Net time of ignition delay

\begin{tabular}{|c|c|c|c|c|c|}
\hline No & $\begin{array}{c}\text { Height } \\
\text { of the ring } \\
(\mathrm{F} .1) \\
\mathrm{h}[\mathrm{mm}]\end{array}$ & $\begin{array}{l}\text { Expansion rate } \\
\text { of the foam } \\
\text { (F.9) } \\
\text { y [-] }\end{array}$ & $\begin{array}{c}\text { Ignition time } \\
\text { gross } \\
(\mathrm{F} .14)(\mathrm{F} .16) \\
\mathrm{t}[\mathrm{sec}]\end{array}$ & $\begin{array}{c}\text { Ignition time } \\
\text { nature } \\
(\mathrm{F} .13) \\
\mathrm{t}[\mathrm{sec}]\end{array}$ & $\begin{array}{c}\text { Ignition time } \\
\text { net } \\
(\mathrm{F} .15)(\mathrm{F} .17) \\
\mathrm{t}[\mathrm{sec}]\end{array}$ \\
\hline 1. & \multirow{4}{*}{2} & 0 (water) & 108 & 19 & 89 \\
\hline 2. & & 6 & 45 & 19 & 26 \\
\hline 3. & & 9 & 42 & 19 & 23 \\
\hline 4. & & 12 & 36 & 19 & 17 \\
\hline 5. & \multirow{4}{*}{3} & 0 (water) & 153 & 19 & 134 \\
\hline 6. & & 6 & 51 & 19 & 32 \\
\hline 7. & & 9 & 47 & 19 & 28 \\
\hline 8. & & 12 & 44 & 19 & 25 \\
\hline 9. & \multirow{4}{*}{4} & 0 (water) & 197 & 19 & 178 \\
\hline 10. & & 6 & 58 & 19 & 39 \\
\hline 11. & & 9 & 50 & 19 & 31 \\
\hline 12. & & 12 & 46 & 19 & 27 \\
\hline 13. & \multirow{4}{*}{5} & 0 (water) & 242 & 19 & 223 \\
\hline 14. & & 6 & 60 & 19 & 41 \\
\hline 15. & & 9 & 53 & 19 & 34 \\
\hline 16. & & 12 & 44 & 19 & 25 \\
\hline
\end{tabular}

\subsection{Foam's efficiency and expression by water equivalent}

Secondly, the water content of the foam, expressed by water column happens (F.19). Logically samples covered with water also belong to this series (F.18). Thereafter the ignition delay of water, foam contains is calculated (F.21). Samples covered with water belong again to this series (F.20). Based on the F.17 and F.21 a coefficient created (F.23) expressed the relation between the ignition delay in case of same water quantity but different features (water-foam). As before, samples covered with water also belong to this series (F.15 and F.20) meaning the base to this calculation (F.22) and logically ratio always results 1 (Table 3 ).

Table 3-Coefficient of ignition delay

\begin{tabular}{|c|c|c|c|c|c|c|}
\hline No & $\begin{array}{l}\text { Height of } \\
\text { the ring } \\
\text { (F.1) } \\
\mathrm{h}[\mathrm{mm}]\end{array}$ & $\begin{array}{c}\text { Expansion rate } \\
\text { of the foam } \\
\text { (F.9) } \\
\text { y [-] }\end{array}$ & $\begin{array}{c}\text { Ignition time } \\
\text { net } \\
\text { (F.15) (F.17) } \\
\text { t [sec] }\end{array}$ & $\begin{array}{l}\text { Water content in } \\
\text { water column } \\
\text { height } \\
\text { (F.18) (F.19) } \\
\text { h [mm] }\end{array}$ & $\begin{array}{c}\text { Ignition time of } \\
\text { water quantity } \\
\text { (F.20) (F.21) } \\
\text { t [sec] }\end{array}$ & $\begin{array}{c}\text { Coefficient of } \\
\text { ignition delay } \\
\text { (F.22) (F.23) } \\
\text { Y [-] }\end{array}$ \\
\hline 1. & \multirow{4}{*}{2} & 0 (water) & 89 & 2 & 89 & 1 \\
\hline 2. & & 6 & 26 & 0,333 & 14,8 & 1,76 \\
\hline 3. & & 9 & 23 & 0,222 & 9,9 & 2,32 \\
\hline 4. & & 12 & 17 & 0,167 & 7,4 & 2,3 \\
\hline 5. & \multirow{4}{*}{3} & 0 (water) & 134 & 3 & 134 & 1 \\
\hline 6. & & 6 & 32 & 0,5 & 22,3 & 1,43 \\
\hline 7. & & 9 & 28 & 0,333 & 14,8 & 1,89 \\
\hline 8. & & 12 & 25 & 0,25 & 11,2 & 2,23 \\
\hline 9. & \multirow{4}{*}{4} & 0 (water) & 178 & 4 & 178 & 1 \\
\hline 10. & & 6 & 39 & 0,667 & 29,7 & 1,3 \\
\hline 11. & & 9 & 31 & 0,444 & 19,8 & 1,57 \\
\hline 12. & & 12 & 27 & 0,333 & 14,8 & 1,82 \\
\hline 13. & \multirow{4}{*}{5} & 0 (water) & 223 & 5 & 223 & 1 \\
\hline 14. & & 6 & 41 & 0,833 & 37,2 & 1,1 \\
\hline 15. & & 9 & 34 & 0,555 & 24,8 & 1,37 \\
\hline 16. & & 12 & 25 & 0,417 & 18,6 & 1,34 \\
\hline
\end{tabular}


Table 4-Foam's extra ignition delay and its expression by water equivalent

\begin{tabular}{|c|c|c|c|c|c|}
\hline No & $\begin{array}{l}\text { Height } \\
\text { of ring } \\
\text { (F.1) } \\
\mathrm{h}[\mathrm{mm}]\end{array}$ & $\begin{array}{l}\text { Expansion rate of } \\
\text { the foam } \\
\text { (F.9) } \\
\text { y [-] }\end{array}$ & $\begin{array}{c}\text { Coefficient of ignition } \\
\text { delay } \\
\text { (F.22) (F.23) } \\
\text { Y [-] }\end{array}$ & $\begin{array}{c}\text { Water content } \\
\text { in water column } \\
\text { height }(\mathrm{F} .18)(\mathrm{F} .19) \\
\mathrm{h}[\mathrm{mm}]\end{array}$ & $\begin{array}{l}\text { Water equivalent of } \\
\text { ignition delay } \\
\text { (F.24) (F.25) } \\
\mathrm{Z}[\mathrm{mm}]\end{array}$ \\
\hline 1. & \multirow{4}{*}{2} & 0 (water) & 1 & 2 & 2 \\
\hline 2. & & 6 & 1,76 & 0,333 & 0,586 \\
\hline 3. & & 9 & 2,32 & 0,222 & 0,515 \\
\hline 4. & & 12 & 2,3 & 0,167 & 0,384 \\
\hline 5. & \multirow{4}{*}{3} & 0 (water) & 1 & 3 & 3 \\
\hline 6. & & 6 & 1,43 & 0,5 & 0,715 \\
\hline 7. & & 9 & 1,89 & 0,333 & 0,629 \\
\hline 8. & & 12 & 2,23 & 0,25 & 0,558 \\
\hline 9. & \multirow{4}{*}{4} & 0 (water) & 1 & 4 & 4 \\
\hline 10. & & 6 & 1,3 & 0,667 & 0,867 \\
\hline 11. & & 9 & 1,57 & 0,444 & 0,697 \\
\hline 12. & & 12 & 1,82 & 0,333 & 0,606 \\
\hline 13. & \multirow{4}{*}{5} & 0 (water) & 1 & 5 & 5 \\
\hline 14. & & 6 & 1,1 & 0,833 & 0,916 \\
\hline 15. & & 9 & 1,37 & 0,555 & 0,76 \\
\hline 16. & & 12 & 1,34 & 0,417 & 0,559 \\
\hline
\end{tabular}

Based on the coefficient (F.23) and water content (F.19) of the foam the ignition delay can be calculated expressed by the equivalent of water column (F.25). This equivalent means that water has extra ignition delay effect in case of foam formulas (Table 4).

\section{Evaluation}

As a first step, the ignition time of samples without treatment (nature) was measured. For the correct base nature samples were measured also during series. Precision of measuring ignition time was below 1 second. Based on 6 samples the average ignition time is 19 seconds with minimal deviation $(+3 /-2$ seconds).

In the series, the samples covered with water were measured firstly. To make measurement more precise, the $2 \mathrm{~mm}$ high ring samples were filled with water using hypodermic syringe, to make the volume precise.

$$
V=h A=h \frac{d^{2} \Pi}{4}=2 \times 10^{-3} \mathrm{~m} \frac{\left(60 \times 10^{-3} \mathrm{~m}\right)^{2} \times 3,14}{4}=5,652 \times 10^{-6} \mathrm{~m}^{3}=5,65 \mathrm{~cm}^{3}
$$

Based on five measures the average ignition time was 108 seconds, with $+15 /-18$ seconds maximal deviation; the rate of deviation is not bigger than with natural samples.

The speciality of water series was that no more measures with precision could be carried out with higher ring on samples. Unfortunately the rings separated from the sample surface $(3 \mathrm{~mm})$ and causing some water leakage during tests spoiled the genuine process. The problem was identified as a minimal deformation of samples' surface caused by water and cement was not enough flexible to compensate the minimal gap. Therefore in case of 3-4-5 mm high ring there was no measured value only calculated in scale based on linear interpolation.

Due to the above, some results can be taken into account with due critical considerations; and additional test series are also required. But results were evaluated as a tendency rather than principle of each measured data. 
Time of igrition us Depth of foam

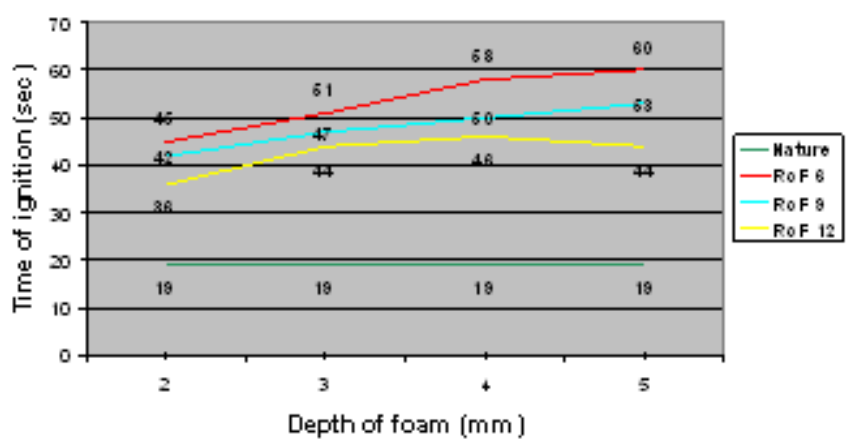

Net ti me of ignitior

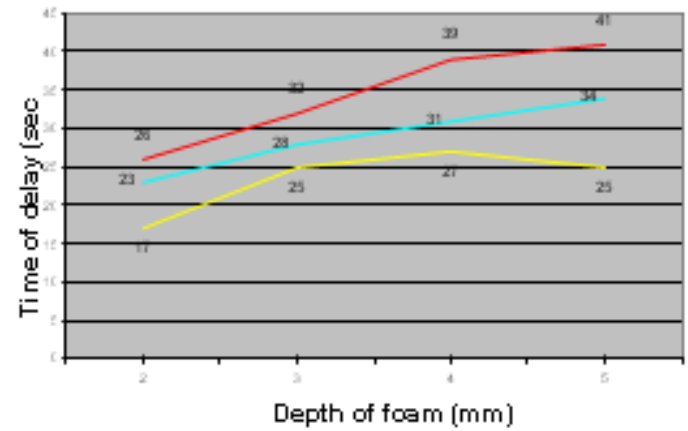

Figure 1. Time and Net time of Ignition versus Depth of foam

In the next series the different expansion rated foams were tested with different depth of blanket covering the samples. The same quantities of foam in each sample were assured by rings. The measured values are in the Table 1 and Figure 1 also shows values in the graphics. The graphics show not just the time of ignition but the tendency of the change hanging on the depth of foam covering samples.

The study focused on the inspection of how the ignition delay changed and what is the tendency of it hanging on the own quality of the foams. That is why the ignition time of not treated sample (nature) required subtracting from the ignition time of treated samples (water and foam). In this case the data shows the "net ignition time" of substances hanging on their own features (Figure 1). Based on measured data and graphics next conclusion were stated:

1. Rising the depth of foam covering samples the time of ignition delay also rise. Tendency yes, but exact data for rising characteristic was not established; more test needed.

2. Rising the depth of foam a special symptom, co-called "foam boiling" was observed. This symptom was more intensive during raising the depth of foam, especially in case of $5 \mathrm{~mm}$ foam blanket with high expansion rated foam (exp. rate $=12$ ). It modified the result, obviously reduced the delay of ignition time.

3. Taking into account the symptom of foam boiling (see above) and the curve tendency of foams (expansion rate is $6-9$, and depth of foam is $2-5 \mathrm{~mm}$ ) the tendency more or less can be also linear.

4. Since the technical difficulties and the assumed rate for higher mistake this study didn't measure the $1 \mathrm{~mm}$ high ring samples, however the Figure 2 generated the data by linear interpolation.

The effect of foam's ignition delay is aggregated by two different factors as below; the first counts with the quantity, the other with the quality:

Factor of quantity: Mechanical foam is made of special solution and air bulbs; solution consists of pure water and special foam agent. The mixture rate hangs on conditions intervention having; ratio is required usually between $0.1-6 \%$. During the study of R-20 method $3 \%$ solution was used. Since the rate was relatively low and the heat capacity of the agent doesn't differ drastically from the water, the value of solution was taken equal to water. Obviously during the test radiation heat evaporated the solution meaning that its heat capacity influenced the ignition time, delayed it similarly to water.

Factor of quality: Foam has a special effect not just having water quantity. Isolation, the additional feature of foam is an extra effect. Fire fighters often use this isolation effect even if the practice does not know exactly what is it or with more precisions what the background of this effect is. Obviously the isolation effect often means defence against radiation heat but also separation between flammable liquid and oxygen. R-20F method focuses on the study of the extra effect caused by the special feature 
of foam. The interest focuses not on the feature of foam but finding a common scale expressing this extra effect and measures these with water equivalent, understood by any fire fighter.

If the foam produces longer ignition delay than ignition delay belongs to its own water quantity, it means that this extra effect is caused by the special features the foam has.

In order to reduce the possibility of mistake during test, series started from $2 \mathrm{~mm}$ high covering. Value before it was rated logically. Figure 2 left from the broken line shows the estimated value, right the measured except in case of water. Problem of water was mentioned above.

Based on the own water quantity of foam (F.7) the ignition delay belonged to it was determined by linear interpolation (F.9). Dividing the time of measured ignition delay to its own water quantity results a rate. If the value of this rate is more than 1 means that foam has extra delay effect (F.11).

Based on the R-20F study the analysis of measured data resulted that this rate is significantly always more than 1. It means that foam has extra isolation effect than just the effect of its own water quantity.

Time of ignition vs Depth of foam

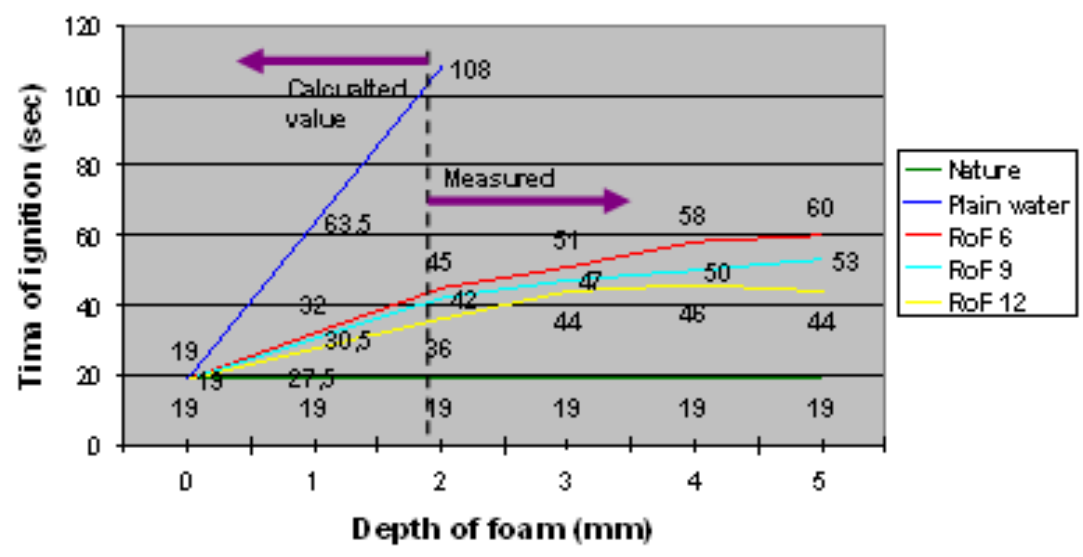

Figure 2. Measured and interpolated value of ignition time

The efficiency of foams with different features is represented in different functions as can be seen below:

1. Expansion rate on "x" axis and hanging on depth of foam efficiency shown in Figure $3 a$;

2. Depth of foam on "x" axis and hanging on expansion rate efficiency shown Figure $3 b$;

3. For better demonstration both diagram were made in 3 dimensional versions using belt diagrams Figure $4 a$ and Figure $4 b$.

Based on experience during the test, calculations and graphics there are statements as can be seen below:

1. The efficiency of foam rises with raising the expenditure rate. The characteristic of this raise can't be surely stated; taking into account the deviations from the average, the near linear curve can't be excluded.

2. The efficiency of foam reduces with raising the thickness. The characteristic of this reduce can't be surely stated; taking into account the deviations from the average, the near linear curve here also can't be excluded (but logically in ideal circumstances it must be).

3. Relatively thin foam blanket but high expansion rate results in high efficiency. 

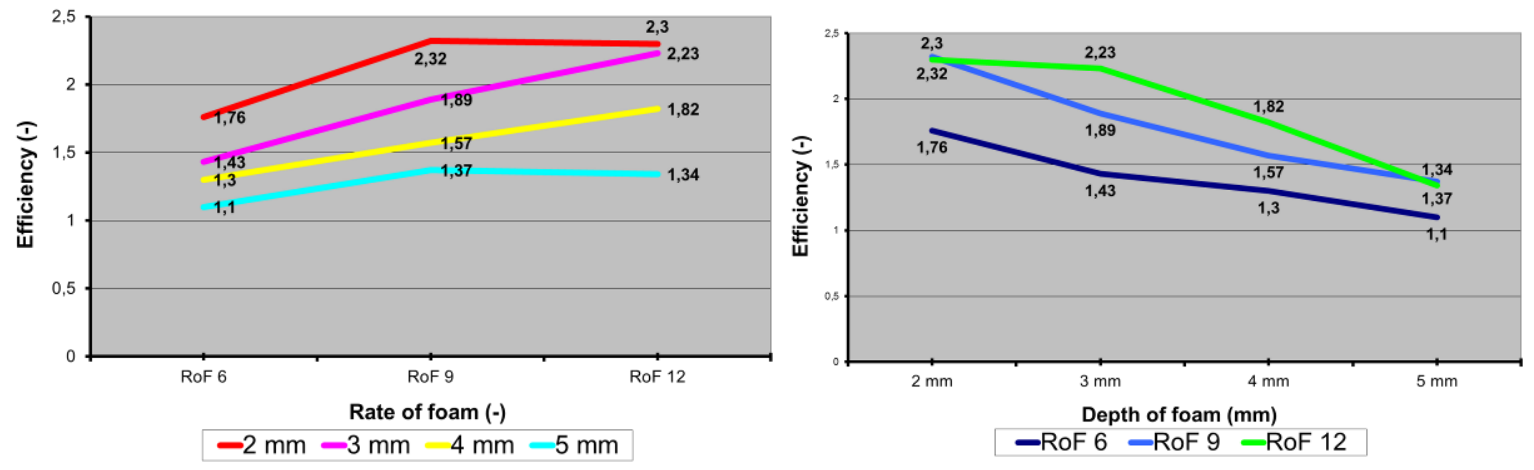

Figure 3. Efficiency versus rate of foam (a) and depth of foam (b)
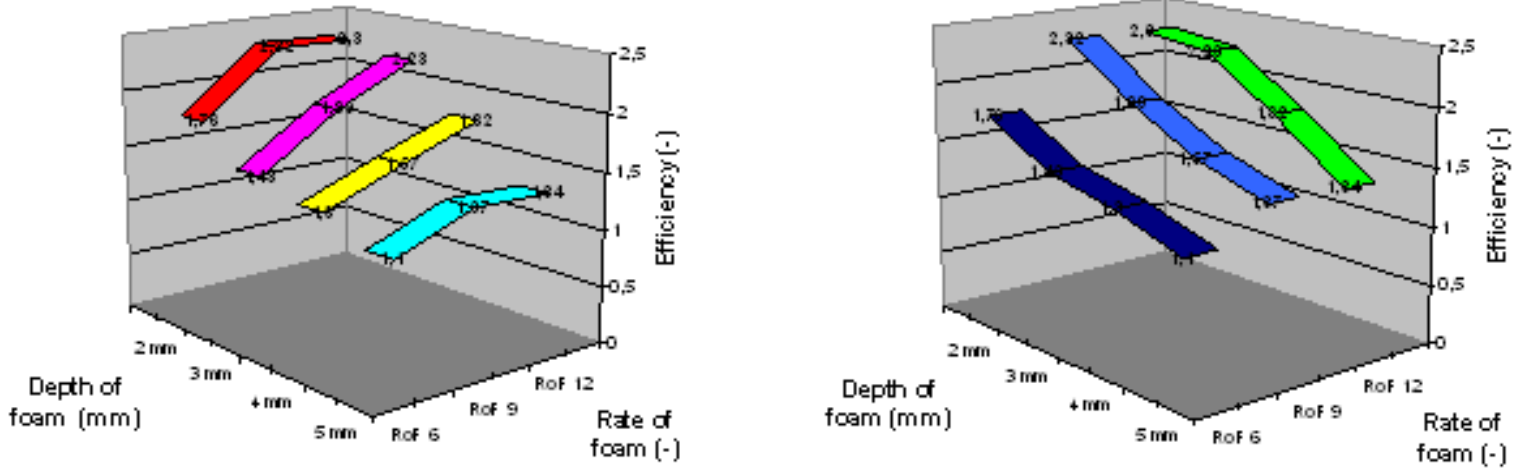

Figure 4. Efficiency versus rate of foam (a) and depth of foam (b); belt diagrams

After determining the efficiency of foams, R-20F method focuses on the expression of this extra effect by practical method; to be able to explain this extra effect also to fire fighters. Water equality as an easiest way can give the solution (F.25). The water equality of foam with its own water quantity can be also demonstrated in a function shown by Figure 5 . The difference between values in vertical shows also the extra ignition delay effect of foam.

\section{Real and relative water content}

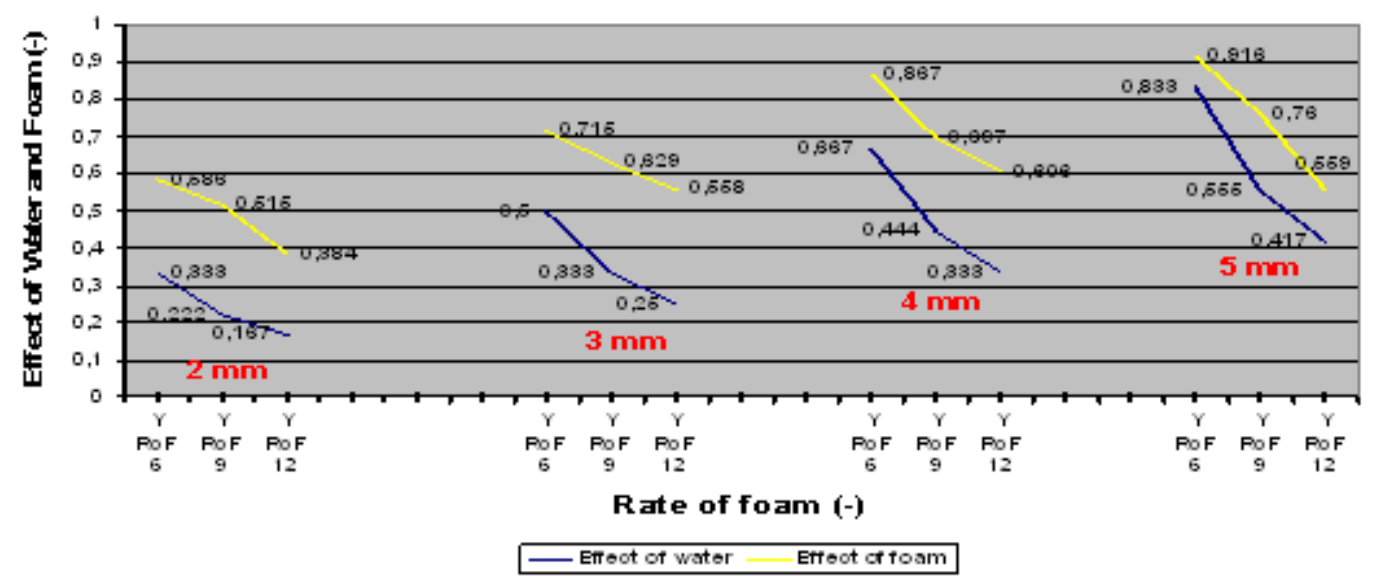

Figure 5. Real and relative water content 
The graphic also demonstrates that raising the thickness of foam $(2 \mathrm{~mm} \Rightarrow 5 \mathrm{~mm})$ moves the curves close to each other; consequently the delay effect reduces. This statement harmonises to Figure 6. With fine analysis it can be observed that the angle with " $x$ " axis rises in both case (real and equivalent water quantity of foam's curve) if thickness of foam blanket also rises.

\section{$Y$ Efficiency of foam}

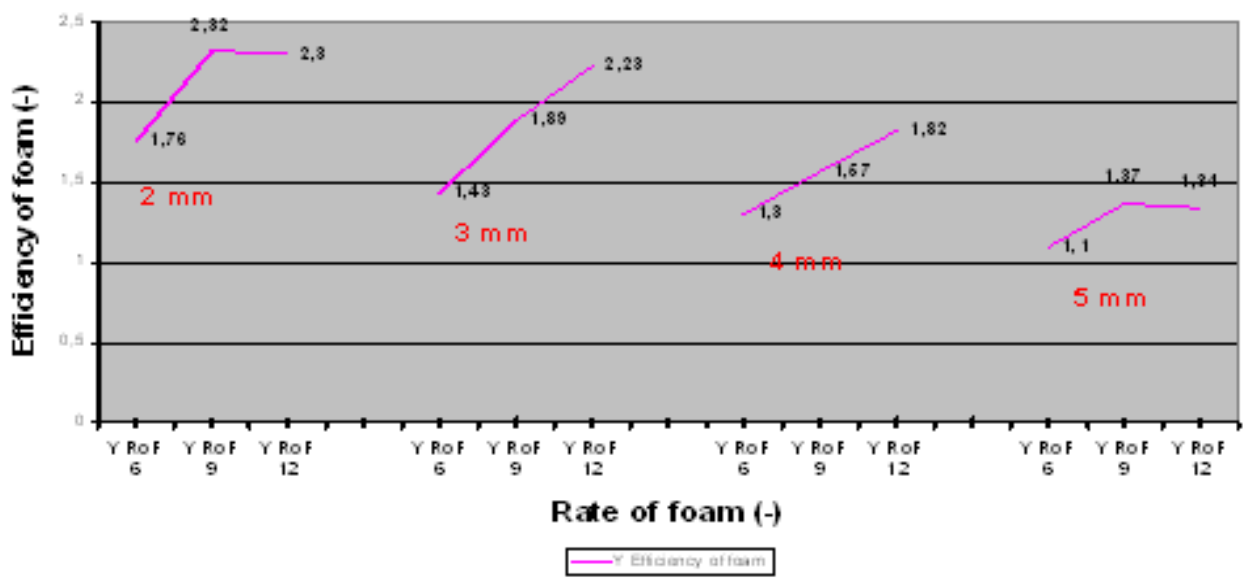

Figure 6. Efficiency of foam

\section{Content and Equivalent of Water}

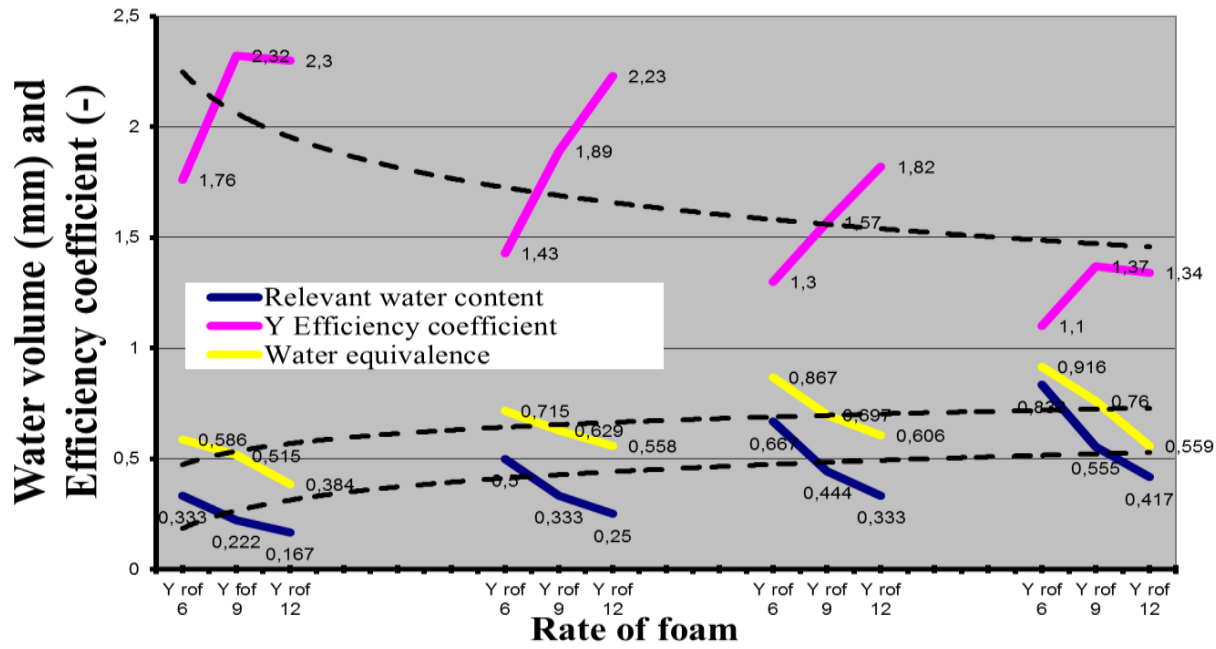

Figure 7. Content and equivalent of water

The coefficient reduces while raising the thickness of foam blanket, parallel to the angle between curves and " $x$ " axis (Figure 7). Harmony is also demonstrated in the function where foams with different features, the real and equivalent water contain of foams and coefficient is represented.

\section{Summarizing}

Based on the R-20F method commonly used firefighting foam was tested. There are many experiences after making test series. Main statements:

1. R-20F is appropriate method to determine the extra effect of foam which is caused by the special feature of the structure and resulted longer ignition delay than should by own water contain. 
2. R-20F is appropriate method drawing conclusion regarding most effective intervention, determine the quality and quantity of foam used especially in case of forest fire.

3. Results given by R-20F method declare that the most effective structure of foam is a relatively thin foam blanket $(\leq 5 \mathrm{~mm})$ but higher expenditure rate than 6 .

For better and more precise results additional test are required using different foam concentrate especially used for fighting forest fires even by aerials. Based on the results some traditional tactic can change and cause more effective fighting against forest fires.

\section{Appendix - Mathematical formulas used for calculations}

1. h Height of the metal ring [mm];

2. $\mathrm{t} \quad$ Ignition time [sec];

3. "h" Upper index, height of water column or thick of foam blanket (height of the metal ring) $[\mathrm{mm}]$;

4. "nature" Lower index, untreated sample;

5. "B" Lower index, gross ignition time [sec];

6. "N" Lower index, net ignition time (measured ignition time reduced by the ignition time of the untreated sample) [sec];

7. "W" Lower index, ignition time of water treated sample [sec];

8. "F" Lower index, ignition time of foam treated sample [sec];

9. "y" Lower index, expansion rate of the foam [-];

10. W Water content of the foam/water expressed by water column height $[\mathrm{mm}]$;

11. Y Effect of ignition delay regarding water content [-];

12. Z Effect of ignition delay expressed by water equivalent [-];

13. ${ }^{t_{\text {nature }}}$ Ignition time, nature sample [sec];

14. $t_{B W}^{h}$

Gross ignition time, sample covered with " $\mathrm{h}$ " mm height water column [sec];

15. $t_{N W}^{h} \quad$ Net ignition time, gross ignition time reduced by $\boldsymbol{t}_{\text {nature }}$, sample covered with " $\mathrm{h}$ " mm height water column [sec]; $\quad t_{N W}^{h}=t_{B W}^{h}-t_{\text {nature }}$

16. ${ }^{t_{B F y}^{h}} \quad$ Gross ignition time, sample covered by ,h" mm thick and “y” expansion rated foam $[\mathrm{sec}]$;

17. ${ }^{t_{N F y}^{h}} \quad$ Net ignition time, gross ignition time reduced by ${ }_{\text {nature }}$, sample covered with " $\mathrm{h}$ " mm thick and "y" expansion rated foam [sec];

$t_{N F y}^{h}=t_{B F y}^{h}-t_{\text {nature }}$

18. $W_{W}^{h} \quad$ Water content of " $\mathrm{h}$ " mm height water column [mm];

19. $W_{F y}^{h} \quad$ Water content of „h” mm thick and ,y” expansion rated foam,

expressed by water column height $[\mathrm{mm}] ; \quad W_{F y}^{h}=\frac{h}{y}$ 
20. ${ }^{t_{W / W}^{h}} \quad$ Ignition time measured $(2 \mathrm{~mm})$ or linear calculated $(3-4-5 \mathrm{~mm})$, sample covered with " $\mathrm{h}$ " mm height water column [sec]; $t_{W / W}^{h}=t_{N W}^{h}$

21. $t_{W / F y}^{h} \quad$ Ignition time calculated with water quantity of foam contains, sample covered by „h" mm thick and ,y” expansion rated foam [sec]; $t_{W / F y}^{h}=\frac{t_{W / W}^{h} W_{F y}^{h}}{W_{W}^{h}}$

22. $Y_{W}^{h} \quad$ Coefficient, meaning the effect of water's ignition delay, sample covered with " $h$ " mm water column, evaluated by water equivalent. Rate $=1[-]$; $Y_{W}^{h}=1$

23. $Y_{F y}^{h}$

Coefficient, meaning the extra effect of foam's ignition delay correlate to its own water content, sample covered with " $h$ " $\mathrm{mm}$ thick and "y" expansion rated foam [-]; $Y_{F y}^{h}=\frac{t_{N F y}^{h}}{t_{W / F y}^{h}}$

24. $Z_{E q u W}^{h} \quad$ Water equivalent of water's ignition delay, expressed by „h” $\mathrm{mm}$ high water column. [mm]; $\quad Z_{E q u W}^{h}=W_{W}^{h}$

25. $Z_{\text {EquFy }}^{h}$ Water equivalent of foam's ignition delay, evaluated by " $h$ " $m m$ height water column equivalent, foam blanket ,x" mm thick and „y" expansion rated foam $[\mathrm{mm}] ; \quad Z_{E q u F y}^{h}=Y_{F y}^{h} W_{F y}^{h}$

\section{References}

Boyd, C.F., Merzo, M. 1996 Fire Protection Foam Behavior in a Radiative Environment; Final Report, Mechanical Engineering Department, University of Maryland, US

Igishev, V.G., Portola V.A. 1993 Evaluation of foam parameters in extinction of self-ignition sources; Mine Aerodynamics, Institute of Mining, Russian Academy of Sciences, Prokopyevsk, FizikoTekhnicheskie Problemy Razrabotki Poleznykh Iskopaemykh, No. 4, Russia

Salgado, J., Paz-Andrade, M.I. 2009 The effect of Firesorb as a fire retardant on the thermal properties of a heated soil; Journal of Thermal Analysis and Calorimetry, Vol. 95 (2009) 3, Akadémiai Kiadó, Budapest, Hungary

STP 2007 Standard Test Procedures, Evaluation of Wildland Fire Chemicals, Lateral Ignition and Flame Spread (LIFT), STP 2.2, Revised 5/30/07, Department of Agricultural, Forest Service, US Source: http://www.fs.fed.us/rm/fire/wfcs/tests/documents/stp_02_2.pdf Internet, Downloaded: 2012.08.28. 